\title{
Mobility and Consequence on Sexual Risk Behavior and HIV Infection among the Kothi (Men Sex With Men) in Puducherry
}

\author{
Ajeet Jaiswal* and Kirubakaran A \\ Department of Anthropology, Pondicherry University, India
}

Submission: May 01, 2017; Published: June 16, 2017

*Corresponding author: Ajeet Jaiswal, Assistant Professors, Department of Anthropology, Pondicherry University, Puducherry, India, Email: rpgajeet@gmail.com

Abstract

Mobility is an important factor contributing to the spread of HIV among key population at risk for HIV; however, research linking this relationship among men who have sex men (MSM) is scarce in India. Mobility is an important factor contributing to the spread of HIV among high risk groups; however, research linking this relationship among men who have sex men (MSM) is scarce in India. This article examines the association between the pattern of mobility and sexual risk behaviour and HIV infection among MSM in Puducherry.

Keywords: HIV/AIDS; Mobility; Risk behaviour; Kothi; MSM

\section{Introduction}

Risky sexual behavior is commonly defined as behavior that increases one's risk of contracting sexually transmitted infections and experiencing unintended pregnancies. They include having sex at an early age, having multiple sexual partners, having sex while under the influence of alcohol or drugs, and unprotected sexual behaviors [1].

Progress in preventing or reducing risky sexual behavior can be assessed by comparing survey results over time. Data on risky sexual behaviors can be collected monthly or quarterly, depending on the length of the program. If risky sexual behavior does not appear to be decreasing at the individual or aggregate level, program managers may want to assess problems related to program design, implementation, and quality. Mobility is the ability and willingness to move or change. People move for many reasons, and factors that drive mobility often stem from unequal distribution of resources, climatic instabil $\neg$ ity, conflict and political unrest. Movements have often been conceptualized as being driven by push or pull factors or a combination of the two.

Mobility has been identified as one of the key vehicles in the transmission of HIV around the world. Several research studies have shown that men who are occupationally mobile are more likely to indulge in risky sexual behaviour such as unprotected sex, having non-spousal sexual partners while away from home thereby increasing their vulnerability to HIV infection [2-7].

\section{Methodology}

Descriptive research method has been adopted for this research. To achieve the goals of this study, the first hand data collection with the help of purposive sampling for case study and pre tested structured Interview schedule was used to full fill the objective and snow ball sampling technique was adopted to select the respondent. The primary data was collected through help of interview schedule by direct participant observation research technique. The data have been collected from the selected samples from different cruising points in Puducherry region where the Kothis indulge in sexual activity. These activities mostly take places in the public parks, public toilets, bus stations, theaters and isolated public places. Such places are well known among the Kothi (MSM) and where they indulge in sexual activities, there is no exact enumerated population size of the MSM in the study area. These people are considered as invisible populations for the correct estimation. The researcher made an attempt to identify the people with MSM (Men who are indulged in Sex with Men) activities, with the help of Sahodaran NGO working on these communities and there by a linkage was established through them in which the Kothis with MSM (Men Sex with Men) activities were selected as the sample study population. By following this snow ball sampling technique a sample of 200 Kothi MSM were identified in Puducherrry region for the research study. 


\section{Definition}

Kothis: The Kothi group has many similarities with the Hijra group, but the main difference is that they tend to be much less feminine than the Hijra. Their main profession is sex work while dressed as females; however, they do not dress as females when they are not working. During anal sex, Kothi are both penetrated and penetrate, while they are also both the givers and receivers in oral sex.

Mobility: Mobility is the ability and willingness to move or change. People move for many reasons, and factors that drive mobility often stem from unequal distribution of resources, climatic instabil-ity, conflict and political unrest. Movements have often been conceptualized as being driven by push or pull factors or a combination of the two.

\section{Result and Discussion}

\section{Mobility of Kothi}

Table 1 shows that 52.0 per cent of the respondents do not like to move from one place to another and 48.0 per cent of them like to move to various places for sexual intercourse

\section{Mobility of the Kothis from Puducherry to Tamilnadu and Other States of India}

From the Table 1 it is inferred that 48.0 per cent of Kothi respondents in the study area move from Puducherry to Tamil Nadu and other states of India. In Tamil Nadu they move frequently in places like Tindivanam, Chennai, Villupuram, Velankanni and Karaikal (Karaikal is belongs to Puducherry Union Territory). Kothis also move frequently to other states of India like Kolkatta, Pune, and Mumbai for their sexual activity and earn money from that.

Table 1: Preference to Move from Place to Place for Sexual Intercourse.

\begin{tabular}{|c|c|c|c|}
\hline Sl. No. & Response & Frequency & Percentage \\
\hline 1 & Yes & 96 & 48 \\
\hline 2 & No & 104 & 52 \\
\hline Total & & 200 & 100 \\
\hline
\end{tabular}

\section{Map showing the frequent mobility of Kothi's from Puducherry to other states of India}

The major cities to which the kothis move in search of sexual partners are from Puducherry to Mumbai, Pune, Kolkata and Chennai (Figure 1).

\section{Map shows the movement of Kothis from Puducherry to the districts of Tamilnadu}

The major places of movement by the Kothis in search of their sexual partners within the Tamilnadu states from Puducherry to Tindivanam, Chennai, Villupuram, Karaikal and Velankanni (Figure 2).
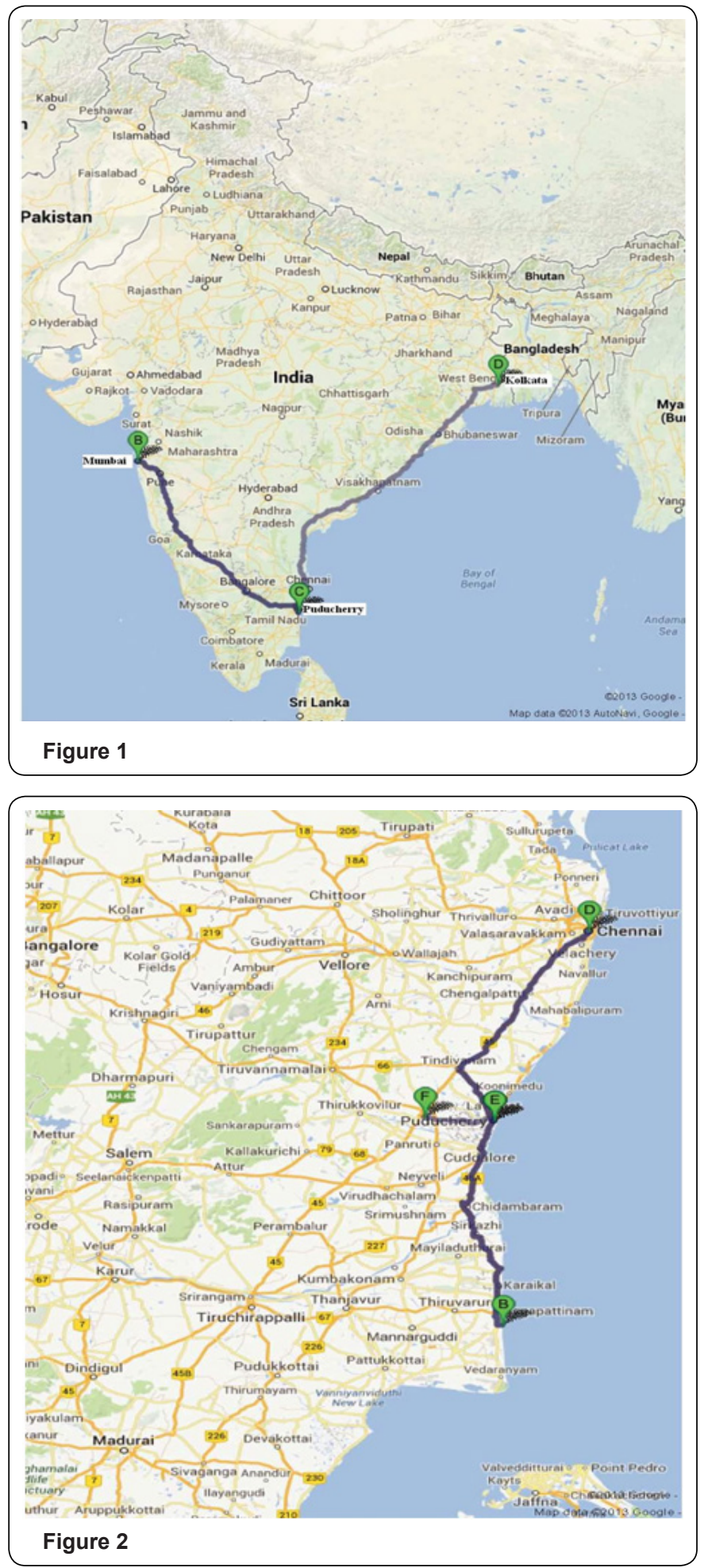

Table 2 shows that 47.9 per cent of Kothi respondents move to other places for their sexual intercourse twice a month, 26.0 per cent of them thrice per month and 18.8 per cent of them once in a 'month. 5.2 per cent and 2.1 per cent of the Kothi respondents move four to five times per Month. 
Table 2 : Frequency of Movement per Month for Sexual Intercourse.

\begin{tabular}{|c|c|c|c|}
\hline Sl. No. & No. of times per month & No. of MSM & Percentage \\
\hline 1 & Once & 18 & 18.8 \\
\hline 2 & Twice & 46 & 47.9 \\
\hline 3 & Thrice & 25 & 26 \\
\hline 4 & Four & 5 & 5.2 \\
\hline 5 & Five & 2 & 2.1 \\
\hline \multicolumn{2}{|c|}{ Total } & 96 & 100 \\
\hline
\end{tabular}

Table 3 reveals that 88.5 per cent of Kothis move from one place to another place for sexual intercourse to earn more to raise their standard of living and survival. 6.3 per cent move to get new sexual partners and 5.2 per cent to get more pleasure to do sex with Panthi's

Table 3: Reason to move from One Place to another for Sexual Intercourse.

\begin{tabular}{|c|c|c|c|}
\hline l. No. & Reason of Movement & Frequency & Percentage \\
\hline 1 & To get more pleasure & 5 & 5.2 \\
\hline 2 & $\begin{array}{c}\text { To get new sexual } \\
\text { partner }\end{array}$ & 6 & 6.3 \\
\hline 3 & To Earn more money & 85 & 88.5 \\
\hline \multicolumn{2}{|c|}{ Total } & 96 & 100 \\
\hline
\end{tabular}

The above Table 4 shows that 62.5 per cent of the Kothi respondents have three to five sexual partners in a day during their outstation stay, followed by 27.1 per cent of them have One or two partners and 10.4 per cent have more than five partners per day.

Table 4: Number of Sexual Partners the Kothis Have in a Day during Outstation Stay.

\begin{tabular}{|c|c|c|c|}
\hline Sl. No. & No. of Sexual parents & Frequency & Percentage \\
\hline 1 & One - Two & 26 & 27.1 \\
\hline 2 & Three - Five & 60 & 62.5 \\
\hline 3 & Above five & 10 & 10.4 \\
\hline \multicolumn{2}{|c|}{ Total } & 96 & 100 \\
\hline
\end{tabular}

The above Table 5 shows that 5.2 per cent of the Kothi respondents have only Oral sex with Panthi during the outstation. One Kothi prefers only anal sex and 6.3 per cent of them prefer masturbation. Most of the respondents ie.87.5 per cent of them have all the three types of sex (Oral, Anal and Masturbation) during outstation stay. Table 6 shows that 71.9 per cent of respondents always use condoms at the time of sexual activity, followed by 24.2 per cent of them using condoms some times during their sex and 4.2 per cent of them never use condom. It is inferred from Table 6 that, most of the Kothi respondents are always conscious about their health and avoid getting HIV affecting
Table 5: Type of sex during outstation stay.

\begin{tabular}{|c|c|c|c|}
\hline Sl. No. & Type of Sex & Frequency & Percentage \\
\hline 1 & Oral & 5 & 5.2 \\
\hline 2 & Anal & 1 & 1 \\
\hline 3 & Masturbation & 6 & 6.3 \\
\hline 4 & All of the above & 84 & 87.5 \\
\hline \multicolumn{2}{|r|}{ Total } & 96 & 100 \\
\hline
\end{tabular}

Table 6: Usage of Condom with the Sexual Partner during Outstation Stay.

\begin{tabular}{|c|c|c|c|}
\hline Sl. No. & Use of Condom & Frequency & Percentage \\
\hline 1 & Never & 4 & 4.2 \\
\hline 2 & Sometimes & 23 & 24 \\
\hline 3 & Always & 69 & 71.9 \\
\hline \multicolumn{2}{|c|}{ Total } & 96 & 100 \\
\hline
\end{tabular}

\section{Conclusion}

The study infers that about 63.0 per cent of the Kothis do not like to move from place to place in search of their sexual partners, but 37.0 per cent of them move to other place which tends as an carrier of infection. They usually move to the neighbouring state of Tamil Nadu, where the frequent moving places are Tindivanam, Chennai, Villupuram, Velankanni and Karaikal. Kothis of Puducherry even travel to distant cities of other ststes like Kolkata, Pune, and Mumbai for their sexual activity and earn money. The movement will be twice a month or even thrice a month. During their mobility Kothis stay in lodges and friends' rooms. Their stay may extend even 2-4 days. The main purpose of the movement is to earn more from sex work, survival and pleasure. The income during the outstation stay ranges from Rs. 300-2000 per visit and at the same time some of them do not mind money but they are in need of pleasure. Kothis themselves search their sexual partners during the outstation stay. They have 2-3 partners per day. In the outstation stay Kothis respondents involve receptive anal, oral and masturbations sexual activities. 28.0 per cent of Kothis have reported that they do not use condom during out station stay. In the out station stay a few Kothis have faced sexual harassment by their partners and local rowdies [8-16].

\section{Suggestion}

I. The Kothis moving from Puducherry to other states should use condom during the sexual activity, to avoid the HIV transmission.

II. Kothis should insist their sexual partners to use condom compulsory during the sexual activity. If they are not willing to use condom, Kothis should avoid sex with them.

III. Puducherry Kothis should insist the foreign sexual customers to use condom during their sexual intercourse.

IV. After consuming alcohol both Kothi and their sexual partner should avoid sexual activity. If they want, they should condom compulsory. 
V. NGO's should concentrate on providing awareness to the Kothis regarding the consequence of alcohol consumption.

VI. Central and State government should provide adequate resources (financial and man power) for HIV/AIDS intervention programs for Kothi (MSM) in Puducherry.

VII. There is an urgent need for national HIV/STD prevention strategy for Kothi (MSM) population, who are at great risk for HIV infection. Such strategy should reflect the cultural, linguistic, educational and socioeconomic status and age diversity among the Kothi (MSM) population.

\section{References}

1. (2010) Centers for Disease Control and Prevention

2. Saggurti N, Jain AK, Sebastian MP (2012) Indicators of mobility, socioeconomic vulnerabilities and HIV risk behaviours among mobile female sex workers in India. Aids Behav 16(4): 952-9

3. Saggurti N, Schensul S, Verma RK (2009) Migration, mobility and sexual risk behavior in Mumbai, India: mobile men with non-residential wife show increased risk. Aids And Behavior 13(5):921-927

4. Deane KD, Parkhurst JO, Johnston D (2010) Linking migration, mobility and HIV. Trop Med Int Health 15(12):1458-1463

5. Nepal B (2007) Population mobility and spread of HIV across the IndoNepal border. J Health Popul Nutr 25(3): 267-77

6. Hope KR (2001) Population mobility and multi-partner sex in Botswana: Implications for the spread of HIV/AIDS. Afr J Reprod Health 5(3): 73-83

7. Saggurti N, Verma RK, Jain A (2008) HIV risk behaviours among contracted and non-contracted male migrant workers in India: potential role of labour contractors and contractual systems in HIV prevention.AIDS 22(Suppl 5): S127-136

8. Verma RK, Saggurti N, Singh AK (2010) Alcohol and sexual risk behavior among migrant female sex workers and male workers in districts with high in-migration from four high hiv prevalence states in India. Aids Behav 14(Suppl 1): S31-9

9. Halli SS, Buzdugan R, Moses S (2010) High-Risk Sex Among Mobile Female Sex Workers In The Context Of Jatras (Religious Festivals) In Karnataka, India. Int J Std Aids 21(11): 746-751

10. Population Council. Patterns of migration/mobility and HIV risk among female sex workers: Andhra Pradesh. New Delhi, India: Population Council, 2008

11. Van Blerk L (2007) Aids, Mobility and Commercial Sex in Ethiopia: implications for Policy. Aids Care 19(1): 79-86

12. Baral S, Sifakis F, Cleghorn F (2007) Elevated risk for HIV infection among men who have sex with men in low- and middle-income countries 2000-2006: a systematic review. Plos Med 4(12): E339.

13. Go VF, Srikrishnan AK, Sivaram S (2004) High HIV prevalence and risk behaviors in men who have sex with men in Chennai, India. J Acquir Immune Defic Syndr 135(3): 314-319

14. Lane T, Raymond HF, Dladla S (2011) High HIV prevalence among men who have sex with men in Soweto, South Africa: results from the Soweto men's study. Aids Behav 15(3): 626-634

15. National Aids Control Organisation (Naco) (2006) National Behavioural Surveillance Survey (Bss): General Population, 2006. New Delhi, India: National Aids Control Organisation

16. Asthana S, Oostvogels R (2001) The Social Construction Of Male 'Homosexuality' In India: Implications For Hiv Transmission And Prevention. Soc Sci Med 52(5): 707-721.

\begin{tabular}{|l|}
\hline \multicolumn{1}{|c|}{ Your next submission with Juniper Publishers } \\
will reach you the below assets \\
- Quality Editorial service \\
- Swift Peer Review \\
- Reprints availability \\
- E-prints Service \\
- Manuscript Podcast for convenient understanding \\
- Global attainment for your research \\
- Manuscript accessibility in different formats \\
( Pdf, E-pub, Full Text, Audio) \\
- Unceasing customer service \\
Track the below URL for one-step submission \\
https://juniperpublishers.com/online-submission.php
\end{tabular}

